Synthesis of Linear Communication Networks Vols. 1 and 2. By Wilhelm Cauer. Second edition edited by Wilhelm Klein and Franz M. Pelz. Translated from the German by G. E. Knausenberger. (McGraw-Hill Electrical and Electronic Engineering Series.) Pp. xxxvi + 866. (London: MeGraw-Hill Publishing Company, Ltd., 1958.) $151 s$.

1 HE classical work of W. Cauer on network synthesis was first published in 1941 and has only now appeared in an English translation. During the fourteen years since the death of Cauer there have been many developments in network theory which have been treated at length in a number of recently published text-books. But Cauer's work cannot be regarded as out of date nor is his book in competition with these modern American texts. Rather is it one of those permanent collections of work from which modern theory derives.

The first part of the book contains a thorough treatment of one-terminal pair and two-terminal pair networks along lines which have now become familiar. The image-parameter network is treated in very great detail and considerable attention given to the design of filters. In the second part, Cauer treats reactance networks in general and expands the theory of frequency band-separation networks, a subject neglected in most other works.

An attempt is made to bring Cauer's work up to date by the inclusion of a 44-page appendix outlining the recent advances in network theory and presenting a classified bibliography containing about 450 references.

\section{Advanced Analytical Chemistry}

By Prof. Louis Meites and Prof. Henry C. Thomas. With a chapter on Infrared Radiation by Prof. Robert P. Bauman. Pp. xi +540 . (London : McGrawHill Publishing Company, Ltd., 1958.) 69s.

MODERN thought in analytical chemistry centres largely in the field of instrumental or physicochemical methods; this is reflected in the evergrowing number of text-books dealing with this subject, either alone or as part of a study of 'advanced analytical chemistry'.

The present book, written by two authoritios in the field of electrochemistry (as applied to analytical chemistry), is basically the outcome of seven years experience in teaching undergraduate and graduate students at Brooklyn Polytechnic and the University of North Carolina. On reading this book one can only envy these students their courses of instruction.

The book is divided into twelve formal chapters which take the reader from a short but exeellent discourse on the nature of analytical chemistry to a similarly well-written account of ionic equilibria in solutions and then to a series of chapters dealing with selected methods of instrumental analysis. These include $p \mathrm{H}$ and redox potentiometry, conductometry, polarography and amperometry, electrolytic methods, spectrophotometry (visible, ultra-violet and infrared), radiochemistry and finally ion exchange and chromatography. This part of the text is concluded by a chapter on the development of an analytical method; this unusual inclusion in a student text is commendable in that it illustrates admirably the nature of analytical chemical research. A number of appendixes then interrupt the text and these are followed by a longish (116 pages) section devoted solely to about ninety practical applications of the methods discussed earlier.
Unlike many books on this subject, the present one gives prominence to the theory of the methods, although unifying this theory with the practical exercises. The instruments themselves are subordinated to the theory underlying their use and it is indeed refreshing to find that the student is taught the essentials of a method so well, often on simple instruments, that when he encounters a more elaborate instrument he can "confidently be referred to the manufacturer's instruction book for information on how to turn the knobs".

Much could be said about this book, but in the end the conclusion would be the same--an excellent book, and well worth study not only by students but also by research workers in analytical chemistry.

W. I. STEPHEN

The Structure and Properties of Porous Materials Proceedings of the Tenth Symposium of the Colston Research Society held in the University of Bristol, March 24th-March 27th, 1958. Edited by D. H. Everett and F, S. Stone. Pp. xiv +389 . (London: Butterworths Scientific Publications; New York: Academic Press, Inc., 1958.) 60s. ; 12 dollars.

7 HIS is a collection of papers from the tenth Colston Research Symposium held in Bristol last year. Its scope may be indicated by listing the authors: Rideal ; Barrer ; Wynne-Jones; Kington; de Boer ; Everett; Dacey and Fendley; Flood; Wiggs; Kiselev; Foster and Thorp; Schofield; Mougey, François-Rossetti and Imelik; Kavtaradze; Rance; King ; Honeybone and Harris; Preston. As the names indicate, the authors' interests range from almost pure physics to biology. The verbal discussions are particularly interesting, and show a fair degree of cross-fertilization. They have been taken from tape recordings, and the temptation to over-edit has been avoided. A few staccato exchanges read like verbatim reports of cross-examination, and the flavour of the individual contributions has been rotained. The reviower approves of this, though he can conceive that this approval will not be universally shared.

Demographic Yearbook 1958

(Special Topic: Marriage and Divorce Statistics.) Pp. viii +541 . (New York: United Nations; London: H.M. Stationery Office, 1958.) Cloth, 8 dollars; 57s.; 34 Swiss francs. Paper, 6.50 dollars ; 46s. ; 28 Swiss francs.

THE "Demographic Yearbook" of the United Nations continues to provide the basic data for the population of the world. The 1958 issue which has recently been published shows the annual rate of increase of the world's population over the period 1950-57 to be sixteen per thousand. Central America, with a rate of twenty-six per thousand, is increasing fastest; North-West Europe, with a rate of six per thousand, shows the slowest rate of increase. Figures of births, deaths, birth-rates, death-rates and expectations of life are again included, but the special topic dealt with in this issue is the statistics of marriage and divorce. Data on marriages, the ages of persons married, singly and in combination, and marriage- and divorce-rates are given for the various countries. There is also an introductory chapter in which the uses of nuptiality statistics are discussed.

The volume continues the standard of excellence that one has come to expect from its predecessors. 